which the coast has been plentifully supplied'during the easterly winds.

About the 14th of last month I shot a very fine old male black Redstart in perfect plumage. A pair of Golden Orioles have been in the large gardens at Kingsgate, which were there for nearly a week, but I could not get a shot at them, being so very wild. On Saturday last I also succeeded in shooting, at about five miles from Margate, a good specimen of the Rose-coloured Pastor: there were two of them, one escaped; that which I shot is a male. I have also a good specimen of the Spotted Sandpiper, which was killed last year.

144 High Street, Margate.

S. Mummery.

\title{
SCIENTIFIC APPOINTMENTS IN TRINITY COLLEGE, DUBLIN.
}

It affords us very high gratification, more especially at the present time, when some of our English Universities seem disposed to make a retrograde movement in science, to be able to announce that several appointments for the promotion of Natural Science have recently been made in Ireland's only University. A chair of geology has been founded, and the distinguished Assistant Secretary of the British Association for the Advancement of Science, Mr. John Phillipswho for some time filled the chair of geology in King's College, London-has been appointed to it. With Trinity College a museum has always been connected, but in these days of progress it had become quite of an antiquated character. With the view of making it as extensively useful as possible, particularly in objects of science, a new office-Director of the Museum-has been formed, and $\mathrm{Mr}$. Robert Ball, the well-known Secretary of the Royal Zoological Society of Ireland, elected to fill it, this gentleman making over to the College his own most valuable and extensive collection of natural history. To secure to the College the large collection of plants made by Dr. Coulter in California and Mexico, and to have the benefit of his botanical services, that distinguished traveller was a few years since appointed Curator of the herbarium, and his collection became the property of the University. After his lamented death, which occurred about six months ago, a successor to the new office was sought for, and that most able botanist Mr. William Henry Harvey was elected, the College, as in the case of Dr. Coulter, securing the whole of his very large and important herbarium.

About the same time the chair of botany became vacant, and Dr. George J. Allman, the most rising philosophical naturalist in Ireland, was elected to it. Better appointments than these, individually and collectively, could not have been made, and the enlightened and liberal spirit with which they have been carried out is worthy of all admiration. The best men, without reference to any previous connexion by education with the College, or to any of those external influences which even at great seats of learning will affect elections, were appointed, their eminent fitness alone for the respective offices, without any of the ordinary alloy, deciding the election.

When mentioning these appointments, it is justly due to the me- 
mory of the late Dr. Lloyd, Provost of Trinity College, to state that it was his anxious wish to found a school of Natural History in the University over which he presided, and that it was in immediate course of being carried into effect in the year 1837 when interrupted by his sudden death.

HABITS OF THE MANTIS.

In a letter from Herr Chr. Zimmerman in Rockingham in North Carolina to Dr. Erichson, editor of the 'Archiv fur Naturgeschichte,' in which he quaintly retorts upon the latter for incredulity respecting some former statements of his relative to the food of Mantis Carolina consisting of amphibia, this fact is fully confirmed by the following additional observations :- Your report having come to hand last September, just the time when the Mantides begin to make their appearance, I had abundant opportunities of repeating my experiments. Instead of the little striped lizard (Scincus 5-lineatus) as heretofore, I made use of a species of newt (Salamandra cirrhigera, Holbri) equally active and more abundant. Its fate was as I anticipated. One newt after the other was seized, and to a greater or less extent devoured. In vain did they endeavour, by rapid contortions of the body and blows with the tail, to elude the grasp of the mantis, which, with the head depressed and the hinder part of the body tiited upwards, kept a firm hold of its victim, and ate until it could eat no more. I send you the very specimen of mantis with which these experiments were performed. Whenever a mantis seizes another insect or small animal, the anterior fang-like extremities are brought down to below the level of the head, so as to avoid having to sustain the weight of the prey.-A.T.

\section{ETHNOLOGY.}

A tract has been published by M. d'Omalius d'Halloy “ Sur les Races Humaines," of which the following is the account given by the author when presenting it to the Academy of Sciences. He states that he had endeavoured to show, that in classing the modifications of the human race, the natural characters, such as form and colour, ought to take the precedence of language, historical filiation, and other social considerations. He then points out that the application of this principle leads him to remove the Hindoos and Abyssinians from the whites and to add them to the brown race, which thus becomes composed of three geographical groups, separated respectively by the Sea of Oman and the Gulf of Bengal. He concludes with remarking upon the constantly progressive development of the whiter varieties of the human race, whilst the coloured races, and also the least fair of the white race, are stationary or retrograde; whence it may be said, that notwithstanding the stability which now characterizes organic nature, there is yet in progress a phænomenon of a like kind with that which is revealed to us in the palæontological study of the terrestrial globe, which exhibits the successive appearance of species more and more perfect; fish having preceded 


\section{$2 \mathrm{BHL}$ Biodiversity Heritage Library}

1844. "Scientific appointments in Trinity College, Dublin." The Annals and magazine of natural history; zoology, botany, and geology 14, 77-78. https://doi.org/10.1080/037454809495139.

View This Item Online: https://www.biodiversitylibrary.org/item/19582

DOI: https://doi.org/10.1080/037454809495139

Permalink: https://www.biodiversitylibrary.org/partpdf/38116

\section{Holding Institution}

Natural History Museum Library, London

\section{Sponsored by}

Natural History Museum Library, London

\section{Copyright \& Reuse}

Copyright Status: Public domain. The BHL considers that this work is no longer under copyright protection.

This document was created from content at the Biodiversity Heritage Library, the world's largest open access digital library for biodiversity literature and archives. Visit BHL at https://www.biodiversitylibrary.org. 